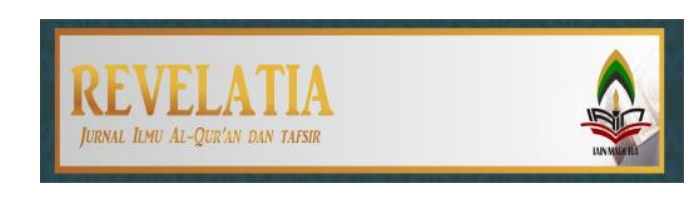

\title{
STUDI LIVING QUR'ÂN IMPLEMENTASI PEMAHAMAN MASYARAKAT TERHADAP SURAH AL-NISÂ' AYAT 36 TENTANG BIRR AL-WÂLIDAYN SETELAH WAFAT DI DESA OMBEN KECAMATAN OMBEN KABUPATEN SAMPANG
}

\author{
Ariej \\ MI Nurul Hidayah Temoran Omben Sampang, \\ Email: ariej.412137@gmail.com
}

\begin{abstract}
Abstrak:
Birr Al-Wâlidayn merupakan perintah Allah untuk berbakti dan berbuat baik kepada kedua orang tua yang harus diikuti dan ditaati setelah perintah beribadah atau bertauhid kepadaNya. Birr al-Wâlidayn tidak hanya dilakukan pada masa orang tua hidup, tetapi dilaksanakan setelah wafatnya pula. Namun, Birr al-Wâlidayn setelah wafat sering kali tidak diperhatikan, karena anak menganggap sudah lepas dari tanggung jawab setelah orang tua wafat. Salah satu tempat yang masih kental dalam melaksanakan atau meyakini adanya kegiatan-kegiatan yang berhubungan dengan oang tua, yaitu di desa Omben kecamatan Omben kabupaten Sampang. Metode yang digunakan dalam penelitian ini adalah kualitatif-deskriptif dengan menggunakan studi living Qur'ân, penggalian datanya melalui wawancara kepada masyarakat (tokoh agama, tokoh masyarakat, atau masyarakat secara umum) terkait pemahaman mereka terhadap surah al-Nisâ' ayat 36 dan implementasinya dalam kehidupan sehari-hari mereka. Hasil dari penelitian ini; pertama, menunjukkan bahwa pandangan masyarakat tentang birr al-Wâlidayn dapat dibedakan menjadi dua, yaitu birr al-Wâlidayn berupa perkataan dan perbuatan. Kedua, indikator birr al-Wâlidayn setelah wafat berupa tanggung jawab anak untuk mengurus jenazah orang tua seperti memandikan, mengafani, menyalati dan menguburkan jenazah orang tua. Kemudian memintakan maaf kepada kerabat dan tetangga, melunasi hutang, melakukan badal haji untuk mereka, dan menyambung silaturahmi dengan teman orang tua. Ketiga, implementasi pemahaman masyarakat terhadap surah al-nisâ' ayat 36 tentang birr al-Wâlidayn setelah wafat di desa omben kecamatan omben kabupaten sampang terdapat beberapa bagian, yaitu kegiatan tahlilan, memperingati empat puluh harinya orang tua yang telah wafat, seratus hari, satu tahun (haul), seribu hari (nyebuh), rebbâ, dan ziarah ke kuburan orang tua.
\end{abstract}

Kata Kunci: Anak; Birr al-Wâlidayn Setelah Wafat; Omben 
Ariej

\section{PENDAHULUAN}

Al-Qur'an adalah kitab suci yang diturunkan kepada Nabi Muhammad saw., menjadi sumber utama ajaran Islam dan merupakan petunjuk kehidupan manusia, karena isinya mengandung segala pokok ajaran agama yang disyariatkan Allah Swt. kepada manusia. ${ }^{1}$ AlQur'an berfungsi sebagai peringatan, petunjuk, penjelas, obat hati dan sebagai bukti kebenaran bagi umat Islam. Sehingga untuk mencapainya, perlu adanya kajian studi AlQur'an atau tafsir, kajian tersebut semakin berkembang pesat seiring berkembangnya ilmu pengetahuan. ${ }^{2}$

Studi yang menjadikan teks Al-Qur'an sebagai objek kajian adalah living Qur'ân, yaitu penelitian ilmiah yang mengkaji tentang fenomena sosial yang berhubungan dengan kehadiran Al-Qur'an di sebuah kelompok Muslim tertentu, dengan tujuan agar masyarakat terhindar dari kecenderungan yang membuat teks-teks Al-Qur'an tidak berfungsi sebagaimana mestinya. ${ }^{3}$ Sehingga Al-Qur'an tidak hanya diartikan sebagai kitab suci saja, tetapi isi dari Al-Qur'an itu sendiri dapat terwujud dalam kehidupan sehari-hari.4

Berbagai pembahasan dalam penelitian Al-Qur'an yang ditekankan pada kehidupan masyarakat dan perilakunya, salah satunya tentang perilaku manusia yang terdapat dalam Al-Qur'an, baik perilaku kelompok terhadap kelompok lain, atau perilaku individu pada kelompok dan sebaliknya, seperti perilaku anak terhadap kedua orang tuanya.

Berbakti (al-Birr) dan berbuat baik kepada kedua orang tua yang telah wafat, menjadi objek utama dalam penelitian ini, setelah melihat banyak orang yang tidak mengetahui secara hakikatnya, bahwa hubungan antara anak dan kedua orang tua tetap bersambung meskipun orang tua telah wafat, salah satunya dengan cara anak mendoakan dan memohonkan ampunan dari Allah swt. kepada kedua orang tua. ${ }^{5}$

Mengingat orang tua yang sejak kecil telah merawat, mendidik dan menjaga hingga dewasa dengan penuh kasih sayang, maka bentuk doa kepada kedua orang tua yang terdapat dalam Al-Qur'an "Wahai Tuhanku, kasihilah mereka keduanya, sebagaimana mereka berdua telah mendidik aku waktu kecil" (Q.S. Al-Isrâ' (17): 24). Jadi, doa tersebut merupakan bentuk permohonan agar Allah mengasihi kedua orang tuanya, secara samar anak tidak rela jika orang tua mendapatkan siksaan, sebagaimana orang tua yang tidak menginginkan anaknya tersakiti.

Terdapat beberapa ayat Al-Qur'an yang menyebutkan tentang perintah berbuat baik kepada kedua orang, ${ }^{6}$ tetapi peneliti fokus pada satu ayat dalam surah al-Nisâ' ayat 36, yaitu sebagai berikut:

\footnotetext{
${ }^{1}$ Said Agil Husain Al Munawar, Al-Qur'an Membangun Tradisi Kesalehan Hakiki (Jakarta Selatan: Ciputat Press, 2002), hlm. 3

2 Pondok Pesantren Safinah Al-Huda, Buku Panduan Program Pelatihan Terjemah Al-Qur'an juz 2, (17 Maret 2010), hlm. i

${ }^{3}$ M. Mansyur dkk, Metodologi Penelitian Living Qur'an dan Hadis (Yogyakarta: Teras, 2007), hlm. 8

${ }^{4}$ Heddy Shri Ahimsa-Putra, The Living Al-Qur'an: Beberapa Perspektif Antropologi. Journal Walisongo. Vol. 20, No. 1 (Mei 2012), hlm. 236

${ }^{5}$ Suad Muhammad Faraj, Berbakti kepada Ibu Bapak Kewajiban Berbuat Baik kepada Kedua Orang Tua Sesuai Al-Qur'an dan Sunnah Nabi, trj. Achmad Sunarto (Yogyakarta: Mitra Pustaka, 2014), hlm. 105.

${ }^{6}$ Lihat, dalam QS. al-Baqarah [2]: 83, al-Nisâ' [4]: 36, al-An'âm [6]: 151, al-Isrâ' [17]: 23, Luqmân [31]: 14, Maryam [19]: 14, al-'Ankabût [29]: 8, al-Ahqâf [46]: 15, al-Ahqâf [46]: 17, Ibrahîm [14]: 41, al-Naml
} 
Studi Living Qur'ân Implementasi Pemahaman Masyarakat Terhadap Surah Al-Nisấ' Ayat 36 Tentang Birr Al-Wâlidayn Setelah Wafat Di Desa Omben Kecamatan Omben Kabupaten Sampang

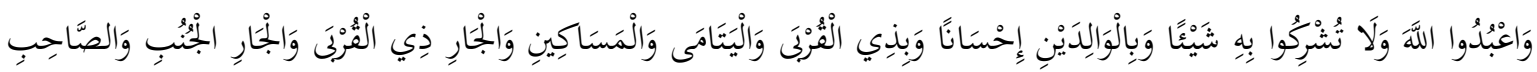

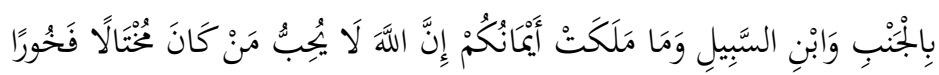

"Sembahlah Allah dan janganlah kamu mempersekutukan-Nya dengan sesuatupun. Dan berbuat baiklah kepada dua orang ibu-bapak, karib-kerabat, anak-anak yatim, orangorang miskin, tetangga yang dekat dan tetangga yang jauh, dan teman sejawat, ibnu sabil dan hamba sahayamu. Sesungguhnya Allah tidak menyukai orang-orang yang sombong dan membangga-banggakan diri. ${ }^{7}$

Perintah birr al-Wâlidayn biasanya bersandingan dengan perintah menyembah Allah, hal ini menunjukkan betapa pentingnya berbakti dan berperilaku baik kepada kedua orang tua, karena keduanya menjadi sebab adanya anak di dunia, walaupun secara dzâhir. Berbuat baik tersebut sebagai bentuk terima kasih kepada kedua orang tua yang telah mengasuh, mendidik, menjaga, dan mengasihi sepanjang masa. ${ }^{8}$

Ketersambungan yang seharusnya tidak terputus, yaitu anak mendoakan orang tua, baik semasa hidup atau setelah wafatnya, karena doa anak terhadap mereka mudah terkabulnya. Jika diukur doa anak kepada kedua orang tua dengan doa orang lain, maka doa anaklah yang lebih diterima, karena pada hakikatnya terdapat ikatan darah dan ikatan batin yang kuat antara keduanya. ${ }^{9}$

Orang tua yang telah wafat, anak tetap dianjurkan untuk berbakti dan berbuat baik kepada mereka, meskipun dengan bentuk dan cara yang sedikit berbeda dari masa hidupnya. Hal ini, dijelaskan dalam hadis sebagai berikut:

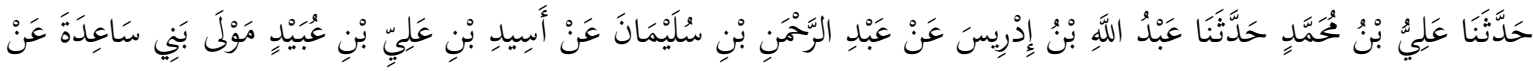

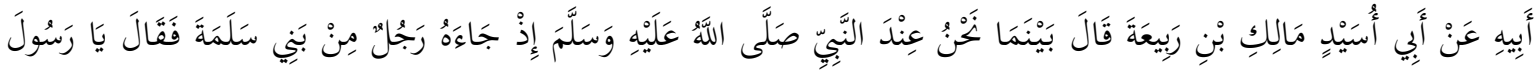

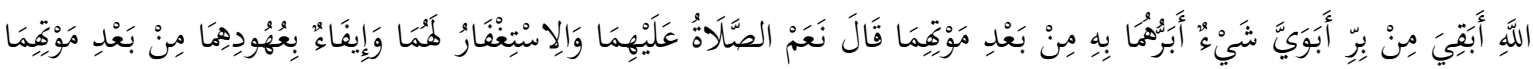

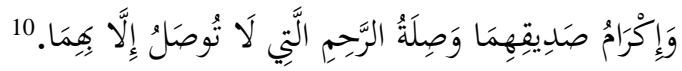

"Ali bin Muhammad menyampaikan kepada kami dari Abdullah bin Idris, dari Abdurrahman bin Sulaiman, dari Asid bin Ali bin Ubaid maula bani Sa'idah, dari ayahnya bahwa Abu Usaid Malik bin Rabi'ah berkata, Tatkala kami berada di dekat Nabi Saw., tiba-tiba seorang laki-laki dari bani Salamah datang kepada beliau seraya berkata, Wahai Rasulullah, apakah masih ada yang bisa aku lakukan sebagai baktiku kepada kedua orang tuaku sesudah kematian mereka? Beliau menjawab, Ya. Doa untuk mereka,

[27]: 19, Nûh [71]: 28, Maryam [19]: 32. Muhammad Fuad Abd. Al-Baqiy, Al-Mu'jam Al-Mufahras Li Alfâdz Al-Qur'ân Al-Karîm (Mesir: Dâr Al-Kutub, 1364), hlm. 764

${ }^{7}$ Departemen Agama RI, Al Qur'an dan Terjemahnya (Surabaya: Al-Hidayah, 2002), hlm. 123

${ }^{8}$ Wahbah Az-Zuhaili, Tafsir Al-Munir. Aqidah, Syari'ah, \& Manhaj jilid 8, trj. Abdul Hayyie Al-Kattani dkk. (Jakarta: Gema Insani, 2016), hlm. 72

9 Mustofa, Guru Agama di Madrasah Nurul Hidayah Kecamatan Omben Sampang, Wawancara lewat telepon, (14 Oktober 2018)

${ }^{10}$ Abi Abdillah Muhammad bin Yazid Al-Qazwini, Sunan Ibnu Mâjah (Libanon: Dar Al-Kotob Al-Ilmiyah, 2009), hlm. 215 
permohonan ampunan untuk mereka, memenuhi janji mereka berdua sepeninggal mereka, menghormati sahabat mereka dan menyambung hubungan persaudaraan yang tidak bisa disambung kecuali karena mereka berdua. ${ }^{11}$

Sebagian masyarakat masih menganggap kegiatan yang dilakukan pada waktu-waktu tertentu, semisal tahlilan,12 empat puluh hari, seratus hari, haul, ${ }^{13}$ seribu hari, rebbâ dan ziarah ke kuburan, sebagai perbuatan yang bid'ah, ${ }^{14}$ karena tidak dicontohkan oleh Nabi Muhammad saw. Jika diteliti lebih mendalam, maka kajian living Qur'an berusaha mengungkap bagaimana orang atau komunitas memperlakukan dan menghayati Qur'an dalam kehidupan sehari-hari mereka. Orang menyebut istilah ini dengan Al-Qur'an in everyday life. Sehingga kegiatan-kegiatan tersebut sebenarnya terdapat implementasi birr alWâlidayn, karena semuanya dilakukan untuk kebaikan orang tua yang telah wafat, yaitu mendoakan untuk keselematan dari siksa kubur.

Fenomena yang sering terjadi, di desa Omben kecamatan Omben kabupaten Sampang, hampir semua anak yang mengikuti kegiatan tersebut, hanya sebatas mengikuti kegiatannya saja, tanpa mengikuti bacaan Al-Qur'an, zikir, doa dan sebagainya, padahal pahala bacaan tersebut akan sampai pada orang tua yang telah wafat, sebagaimana puasa dan haji yang telah ditinggal wafat. ${ }^{15}$

Fokus penelitian dalam artikel ini dapat dibagi menjadi tiga; pertama, pandangan masyarakat tentang birr al-Wâlidayn dapat dibedakan menjadi dua, yaitu birr al-Wâlidayn berupa perkataan dan perbuatan. Kedua, indikator birr al-Wâlidaynsetelah wafat berupa tanggung jawab anak untuk mengurus jenazah orang tua seperti memandikan, mengafani, menyalati dan menguburkan jenazah orang tua. Kemudian memintakan maaf kepada kerabat dan tetangga, melunasi hutang, melakukan badal haji untuk mereka, dan menyambung silaturahmi dengan teman orang tua. Ketiga, implementasi pemahaman masyarakat terhadap surah al-Nisâ' ayat 36 tentang birr al-Wâlidayn setelah wafat di desa Omben kecamatan Omben kabupaten Sampang terdapat beberapa bagian, yaitu kegiatan tahlilan, memperingati empat puluh harinya orang tua yang telah wafat, seratus hari, satu tahun (haul), seribu hari (nyebuh), rebbâ, dan ziarah ke kuburan orang tua.

${ }^{11}$ Abu Abdullah Muhammad bin Yazid Al-Qazwini, Ensiklopedia Hadits 8; Sunan Ibnu Majah, trj. Saifuddin Zuhri (Jakarta: Al-Mahira, 2013), hlm. 659

12 Tahlil secara bahasa merupakan bacaan la ilaha illallahu, sedangkan secara istilah adalah sebuah kegiatan yang didalamnya terdapat bacaan surat al-Fatihah, al-Ikhlas, al-Falaq, al-Nas, awal surat alBaqarah, ayat kursi, tiga ayat akhir surat al-Baqarah, bacaan la ilaha illallah, Subhanallah wa bihamdihi, dan salawat kepada Nabi saw. Lihat, Mohammad Danial Royyan, Sejarah Tahlil Kumpulan Tahlil, Talqin, dan Ziarah Kubur dalam Sejarah dan Argumentasinya (Kendal: LTN-NU dan Pustaka Amanah, 2013), hlm. 1

${ }^{13}$ Haul berarti memperingati masa satu tahunnya seseorang yang telah meninggal dunia, kegiatan ini berawal atau berdasarkan pada Nabi Muhhammad saw. yang ziarah ke kuburan para syuhada di Uhud setiap tahun.Ibid., hlm. 22

${ }^{14}$ Bid'ah adalah suatu perbuatan, perkataan, atau keyakinan yang tidak ada dalam ajaran Islam, baik alQur'ân ataupun hadis. Lihat: Syahrin Harahap dan Bakti Nasution, Ensiklopedia Akidah Islam (Jakarta: Kencana, 2009), hlm. 117

${ }^{15}$ Sa'ad Yusuf Abu Aziz, Buku Pintar Sunnah dan Bid'ah (Yogyakarta: Pustaka Al-Kautsar, 2016), hlm. 424 
Studi Living Qur'ân Implementasi Pemahaman Masyarakat Terhadap Surah Al-Nisấ' Ayat 36 Tentang Birr Al-Wâlidayn Setelah Wafat Di Desa Omben Kecamatan Omben Kabupaten Sampang

Penulis menggunakan pendekatan kualititif, yaitu suatu pendekatan yang dilakukan dalam penelitian untuk mendapatkan data deskriptif, baik berupa data tertulis atau lisan dari orang-orang yang sedang diteliti atau perilaku yang diamati. ${ }^{16}$

Jenis penelitian yang digunakan peneliti adalah penelitian lapangan dalam bahasa lain disebut field research, yakni terjun langsung ke lapangan untuk mendapatkan informasi yang jelas dan utuh. Sifat penelitian yang digunakan adalah deskriptif, yaitu menelusuri langsung ke lapangan untuk memperoleh dan mendapatkan pengetahuan yang lebih dalam, serta menjelaskan tentang fenomena atau kenyataan sosial. ${ }^{17}$

\section{Seputar Birr al-Wâlidayn}

Birr al-Wâlidain terdiri dari dua kata, yaitu kata birr dan al-Wâlidayn. Secara etimologi, kata birr berarti kebenaran, ketaatan, ${ }^{18}$ kesalehan, kebaikan, belas kasih, banyak berbuat kebajikan, dan kedermawanan. ${ }^{19}$ Sedangkan al-walidain berarti bapak dan ibu (kedua orang tua), bentuk kata tunggal ( $m u$ frad) nya berupa al-Wâlid (bapak) dan al-Wâlidah (ibu).

Secara terminologi, kata birr al-Wâlidayn merupakan suatu perbuatan yang menunjukkan bakti seorang anak terhadap kedua orang tua, karena ibu dan bapak menjadi sebab secara zhâhir keberadaan anak di dunia, meskipun pada hakikatnya adalah Allah yang menciptakan segala sesuatu yang ada. ${ }^{20}$

Kewajiban seorang anak dalam berbakti dan berbuat baik kepada kedua orang tua, tetap berlanjut meskipun orang tua telah wafat. Terkadang anggapan seorang anak, birr alWâlidain hanya dilakukan pada masa orang tua masih hidup saja, dan anak merasa sudah lepas dari tanggung jawab untuk birr al-Wâlidain, padahal hal tersebut merupakan kesalahan yang harus diluruskan, karena sudah dinyatakan dalam Al-Qur'an ataupun hadis.

Menambah wawasan tentang birr al-Wâlidayn merupakan keharusan bagi setiap anak, baik pada masa hidup orang tua atau setelah wafatnya, karena sering dilupakan bahkan diabaikan ketika berhadapan dengan kegiatan-kegiatan yang memang ada hubungannya dengan orang tua. Terdapat banyak pembahasan tentang birr al-Wâlidayn, namun penulis fokus pada tiga hal yang dapat membantu penulis dalam penelitian ini.

\section{Pandangan masyarakat tentang birr al-Wâlidayn di desa Omben kecamatan Omben kabupaten Sampang}

Pandangan masyarakat desa Omben kecamatan Omben kabupaten Sampang tentang birr al-Wâlidayn masih bersifat global dan fokus pada satu bentuk saja, yaitu anak yang tunduk terhadap semua perintah kedua orang tua, selama apa yang telah diperintahkan tidak

16 Uhar Suharsaputra, Metode Penelitian Kuantitatif, Kualitatif, dan Tindakan (Bandung: Refika Aditama, 2012), hlm. 181

17 Sanapiah Faisal, Format-Format Penelitian sosial (Jakarta: RajaGrafindo Persada, 1999), hlm. 20

18 Jamal al-Din Abi Al-Fadl Muhammad Al-Anshariy, Lisan Al-'Arab (Libanon: Dar Al-Fikar, 2009), hlm. 59

19 Ahmad Warson Munawwir, Kamus Al-Munawwir Arab-Indonesia Terlengkap (Surabaya: Pustaka Progressif, 1997), hlm. 74

${ }^{20}$ Wahbah Az-Zuhaili, Tafsir Al-Munir. Aqidah, Syari'ah, \& Manhaj jilid 8, trj. Abdul Hayyie Al-Kattani dkk, hlm. 69. 
Ariej

melenceng dari ajaran Islam, karena anak yang sudah tunduk terhadap perintah mereka, berarti ia sudah tergolong birr al-Wâlidayn. ${ }^{21}$

Jika dilihat dari segi bahasa, birr al-Wâlidayn memliki banyak arti, salah satunya dengan cara menghormati orang tua, menjaga kesopanan atau tatakrama serta memenuhi kebutuhan mereka. Selain itu, mendoakan kedua orang tua temasuk birr al-Wâlidayn yang harus dilakukan. ${ }^{22}$ Pendapat ini, sudah mulai mengarah pada pengertian yang lebih mendalam, yaitu mendoakan orang tua. Pada hakikatnya, mendoakan orang tua merupakan salah satu bentuk birr al-Wâlidayn yang dilakukan tidak secara terang-terangan.

Pandangan masyarakat desa Omben kecamatan Omben kabupaten Sampang tentang birr alWâlidayn hampir mempunyai pandangan yang sama antara yang satu dengan yang lainnya. Namun, penulis dapat membagi menjadi dua bagian, yaitu birr al-wâlidayn berupa perkataan dan birr al-wâlidayn berupa Tindakan atau perbuatan.

\section{Birr al-Wâlidayn berupa Perkataan}

Secara bahasa, perkataan merupakan sesuatu yang diucapkan atau diungkapkan. ${ }^{23}$ Sedangkan perkataan secara istilah adalah suatu ucapan yang dapat memberikan dampak bagi orang lain secara jelas, baik dampaknya berupa kebaikan bagi pendengar ataupun tidak, karena dalam hal ini, ucapan yang baik menandakan orang yang baik pula. Sehingga anak dapat dikatakan berbakti dan berbuat baik kepada kedua orang tuanya, ketika ia mampu mengeluarkan perkataan yang baik terhadap mereka.

Terdapat beberapa bentuk birr al-Wâlidayn berupa ucapan atau perkataan yang harus dipraktikkan oleh anak, karena pepatahan mengatakan dengan ucapan yang baik anak mampu membahagiakan kedua orang tua, baik pada masa hidup atau setelah wafatnya. Salah satu bentuknya, yaitu sebagai berikut; Pertama, bentuk berbakti dan berbuat baik kepada kedua orang tua dengan cara mendoakan mereka dan memohonkan ampunan kepada Allah untuk kedua orang tua. Hal ini, sering kali dilupakan oleh anak, padahal doa anak yang diharapkan oleh mereka, demi keselamatan di dunia dan di akhirat, khususnya selamat dari siksa kubur.

Kedua, dilakukan pada masa hidupnya orang tua, yaitu dengan cara menggunakan perkataan yang baik, lemah lembut dan tidak membentak kedua orang tua. Jika dalam seharihari, hati dan ucapan tidak dijaga dan dibiasakan dengan hal yang tidak baik, maka anak akan mudah menyampaikan perkataan yang kasar dan dapat menyakiti hati orang tua. Firman Allah dalam surah al-Isra' ayat 23-24:

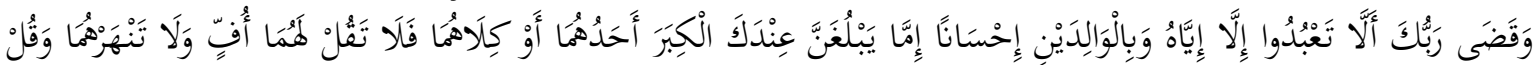

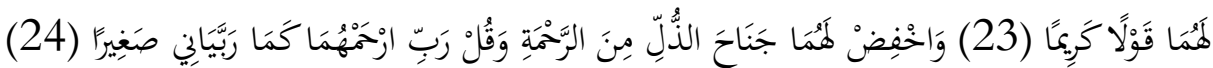

"Dan Tuhanmu telah memerintahkan supaya kamu jangan menyembah selain Dia dan hendaklah kamu berbuat baik pada ibu bapakmu dengan sebaik-baiknya. Jika salah seorang di antara keduanya atau kedua-duanya sampai berumur lanjut dalam pemeliharaanmu, maka sekali-kali janganlah kamu mengatakan kepada keduanya

\footnotetext{
${ }^{21}$ Hasyim, Warga Desa Omben, Wawancara Langsung (15 Januari 2019)

22 Taufiqurrohman, Pengasuh Lembaga Darussalam 2, Wawancara Langsung, (04 Maret 2019)

${ }^{23}$ Departemen Pendidikan Nasional, Kamus Besar Bahasa Indonesia (Jakarta: Gramedia Pustaka Utama, 2008), hlm. 634
} 
Studi Living Qur'ân Implementasi Pemahaman Masyarakat Terhadap Surah Al-Nisâ' Ayat 36 Tentang Birr Al-Wâlidayn Setelah Wafat Di Desa Omben Kecamatan Omben Kabupaten Sampang

perkataan "ah" dan janganlah kamu membentak mereka dan ucapkanlah kepada mereka perkataan yang mulia. Dan rendahkanlah dirimu terhadap mereka berdua dengan penuh kesayangan dan ucapkanlah: "Wahai Tuhanku, kasihilah mereka keduanya, sebagaimana mereka berdua telah mendidik aku waktu kecil". 24

Dalam ayat ini, nampak jelas perintah Allah Swt. untuk berbakti kepada kedua orang tua, karena dalam usia lanjut, orang tua merasa lemah dan ingin ada dalam rangkulan anak. Terkadang anak tidak sabar dalam menghadapi orang tuanya yang sudah lemah dan lanjut usia, padahal ini dosa besar, karena orang tua tidak pernah mengenal lelah dan payah dalam merawat anak, baik dalam mengandung selama sembilan bulan, melahirkan, menyusui hingga dua tahun, merawat ketika sakit, mendampingi dan menjaga hingga tumbuh dewasa dan sampai berkeluarga. Akibatnya anak yang menyakiti kedua orang tuanya dengan ucapan atau perbuatan, ia akan mendapatkan penyesalan dan hidupnya condong tidak bahagia.

\section{Birr al-Wâlidayn berupa Tindakan atau Perbuatan}

Tindakan merupakan sesuatu yang dilakukan, ${ }^{25}$ yaitu dilakukan dengan cara menggunakan salah satu anggota badan, sehingga hasilnya akan tampak dan terlihat. Birr alWâlidayn berupa tindakan lebih menekankan pada orang tua yang sudah lanjut usia, karena kondisi yang mulai melemah dan butuh bantuan anak.

Ketika anak merawat orang tua yang sedang sakit dan lemah, memenuhi kebutuhan mereka, menyayangi dan mengasihi, pada hakikatnya tidak seberapa, jika dibandingkan dengan pengorbanan dan jerih payah orang tua terhadap anaknya. Maka rugilah anak yang tidak berbakti dan berbuat baik kepada mereka.

Semua perintah orang tua harus ditaati oleh anak, selama perintah tersebut tidak keluar dari ajaran Islam atau suatu kemaksiatan. Namun jika demikian, maka boleh tidak mentaati perintah mereka dan tidak dianggap durhaka, tetapi anak diharuskan untuk menghormati menggakan akhlak yang baik. ${ }^{26}$ Firman Allah dalam surat Luqman [31]: ayat 15:

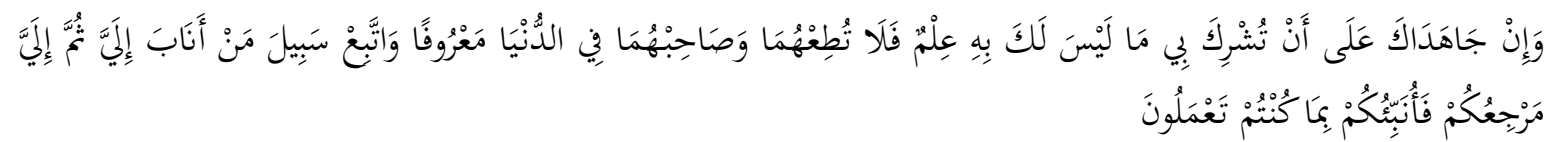

"Dan jika keduanya memaksamu untuk mempersekutukan dengan Aku sesuatu yang tidak ada pengetahuanmu tentang itu, maka janganlah kamu mengikuti keduanya, dan pergaulilah keduanya di dunia dengan baik, dan ikutilah jalan orang yang kembali kepada-Ku, kemudian hanya kepada-Kulah kembalimu, maka Kuberitakan kepadamu apa yang telah kamu kerjakan. ${ }^{27}$

\footnotetext{
${ }^{24}$ Departemen Agama RI, Al Qur'an dan Terjemahnya, hlm. 427

25 Departemen Pendidikan Nasional, Kamus Besar Bahasa Indonesia., hlm. 1467

26 Alwi Abdul Kadir Bik, Birr Al-walidain (Berbakti kepada Kedua Orang Tua), hlm. 48

27 Departemen Agama RI, Al Qur'an dan Terjemahnya, hlm. 654-655
} 
Ariej

Indikator birr al-Wâlidain setelah wafat di desa Omben kecamatan Omben kabupaten Sampang

Indikator birr al-Wâlidain setelah wafat di desa Omben kecamatan Omben kabupaten Sampang dapat dilihat dari beberapa hal yang akan peneliti uraikan yakni mengurus jenazah orang tua, memintakan maaf kepada kerabat dan tetangga, melunasi hutang orang tua, melakukan badal haji kepada orang tua yang telah wafat, jika masa hidupnya tidak sempat melaksanakan haji, tetapi dianggap mampu dan menyambung silaturahmi dengan teman dan kerabat orang tua.

\section{Mengurus jenazah orang tua}

Mengurus jenazah atau tajhâz al-Janâzah saat orang tua wafat yang paling bertanggung jawab dan lebih uatama dilakukan oleh anak, jika segalanya dilakukan oleh orang lain, maka bentuk indikator birr al-Wâlidayn masih kurang, bahkan tidak ada, kecuali anak masih kecil atau tidak kuasa untuk melaksanakannya. Mengurus jenazah terdiri dari empat bagian, yaitu memandikan jenazah orang tua, mengafani jenazah orang tua, menyalati jenazah orang tua dan menguburkan jenazah orang tua.

\section{Memandikan jenazah orang tua}

Pada hari wafatnya orang tua, anak seharusnya mengurus penuh untuk jenazahnya orang tua yang wafat, dengan artian tidak menyibukkan diri dengan mempersilahkan tamu atau memberikan makanan untuk mereka, karena perhatian orang lain tidak sama dengan perhatian dan kehati-hatian anak khususnya dalam memandikan jenazah orang tua.

Memandikan jenazah orang tua merupakan keharusan yang dilakukan oleh anak, karena disamping kewajiban, hal tersebut merupakan indikator birr al-Wâlidayn setelah wafat. Kecuali mati syahid, maka kewajiban memandikan akan gugur Jika Ibu atau wanita yang meninggal, maka yang harus memandikan adalah anak atau sesama wanita, dan jika yang meninggal bapak atau laki-laki, maka yang berkewajiban memandikan adalah anak atau sesama lelaki. ${ }^{28}$

\section{Mengafani jenazah orang tua}

Di samping memandikan jenazah orang tua, anak juga diharuskan ikut serta dalam mengafaninya, baik membeli kain kafan, menyiapkan dan sebagainya, karena keikutsertaan anak dalam hal tersebut akan memudahkan dan mempercepat prosesnya. Maka anak diharuskan lepas dari tanggung jawab yang lain di luar kebutuhan jenazah orang tua. Pembelian kain kafan diutamakan dengan menggunakan harta anak sebagai bentuk indikator birr al-Wâlidayn setelah wafat.

Jika anak tidak mampu, maka diambil dari harta orang tua dengan beberapa ketentuan yang berlaku, jika jenazah laki-laki, maka yang dibutuhkan kain kafan sebanyak tiga lapis, boleh ditambah baju dan serban. Jika jenazahnya wanita, maka membutuhkan kain kafan sebanyak lima lapis, yaitu kain untuk samping, satu baju, satu kerudung, dan dua lapisnya untuk menutupi seluruh bada. ${ }^{29}$

\footnotetext{
${ }^{28}$ Syahrin Harahap dan Bakti Nasution, Ensiklopedia Akidah Islam, hlm. 379

${ }^{29}$ Ibid.
} 
Studi Living Qur'ân Implementasi Pemahaman Masyarakat Terhadap Surah Al-Nisấ' Ayat 36 Tentang Birr Al-Wâlidayn Setelah Wafat Di Desa Omben Kecamatan Omben Kabupaten Sampang

\section{Menyalati jenazah orang tua}

Setelah mengafani jenazah orang tua, maka dilanjutkan untuk menyalati jenazahnya. Pada bagian ini, anak dituntut lebih khusuk dalam melaksanakannya, karena pada saat menyalati jenazah orang tua, doa pertama kali mulai dilakukan oleh anak, sehingga anak diharuskan benar-benar menyatu dengan penuh harapan agar diselamatkan dari siksa kubur.

Terdapat beberapa ketentuan dalam menyalati jenazah, yaitu; pertama, berniat untuk menyalati jenazah. Kedua, berdiri bagi yang sanggup. Ketiga, bertakbir empat kali takbiran. Keempat, membaca surat al-Fatihah setelah takbir al-Ihrâm. Kelima, membaca selawat kepada Nabi Muhammad saw. setelah takbir yang kedua. Keenam, mendoakan mayit setelah takbir yang ketiga. Ketujuh, dilakukan dengan tertib. Kedelapan, salam. ${ }^{30}$

\section{Menguburkan Jenazah Orang Tua}

Anak diharuskan ikut serta dalam menggali kuburan jika mampu hingga proses penguburan berlangsung, jenazah orang tua hendaknya disegerakan untuk dikubur, karena kewajiban yang harus dilakukan oleh anak yaitu menguburkannya, dengan mengikuti ketentuan-ketentuan yang ada, semisal bau tidak tercium ke permukaan bumi dan sekiranya tidak dapat dibongkar oleh binatang buas. ${ }^{31}$

Mengikuti proses penguburan jenazah termasuk indikator birr al-Wâlidain setelah wafat, karena hal ini merupakan tanda bahwa anak memang benar-benar berbakti dan berbuat baik kepada mereka, sehingga ke tempat yang akhir dari segala kehidupan.

\section{Memintakan maaf kepada kerabat dan tetangga.}

Orang yang sudah meninggal, khususnya kedua orang tua dan tidak sempat meminta maaf dengan sendirinya, karena ajal manusia yang tidak terduga datangnya, maka mereka masih memiliki kesempatan untuk dimaafkan melalui anak yang memintakan maaf untuk orang tua yang telah wafat.

\section{Melunasi hutang orang tua}

Melunasi hutang kedua orang tua merupakan keharusan yang dilakukan oleh anak selama ia mampu dan sudah baligh. Menurut ustaz Tamri, hutang orang tua yang telah wafat harus dilunasi dan dipenuhi oleh anak, baik berupa hutang salat, puasa dan hutang uang, meskipun orang tua memiliki bagian masuk surga, tetapi terdapat hutang uang yang tidak dilunasi, maka mereka akan tertunda untuk masuk surga sampai hutangnya terlunasi. ${ }^{32}$

\section{Melakukan badal haji kepada orang tua yang telah wafat, jika masa hidupnya tidak sempat melaksanakan haji, tetapi dianggap mampu}

Badal haji terdiri dari dua kata, yaitu badal yang berarti mengganti dan haji merupakan rukun Islam yang kelima. Jadi, badal haji adalah melaksanakan rukun Islam yang

\footnotetext{
30 Syahrin Harahap dan Bakti Nasution, Ensiklopedia Akidah Islam, hlm. 380

31 Ibid.

32 Tamri, Tokoh Agama di Dusun Bhutmancâng Desa Omben, Wawancara Langsung (7 April 2019)
} 
kelima dengan cara digantikan oleh orang lain. ${ }^{33}$ Salah satu dasarnya bolehnya badal haji, yaitu sebagai berikut:

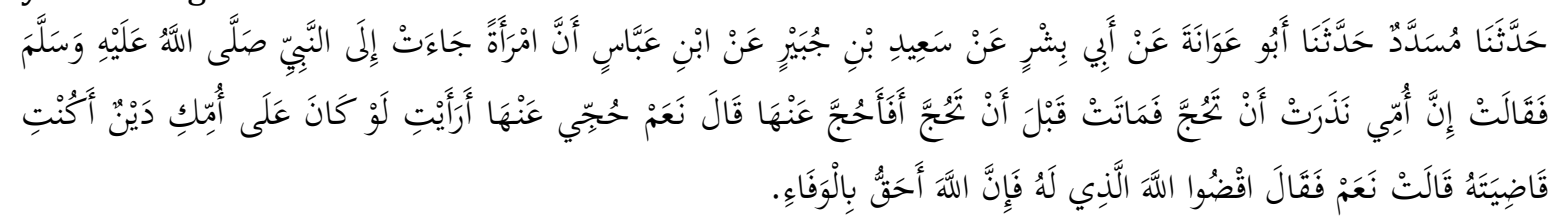

"Telah menceritakan kepada kami Musaddad telah menceritakan kepada kami Abu 'Awanah dari Abu Bisyr dari Sa'id bin Jubair dari Ibn Abbas, bahwa seorang wanita menemui Nabi shallallahu 'alaihi wasallam dan berujar, "Ibuku bernadzar untuk haji, hanya terburu meninggal dunia, bolehkah aku menggantikan hajinya?" Nabi shallallahu 'alaihi wasallam menjawab: "Silahkan, berhajilah engkau untuk menggantikannya, bukankah engkau sependapat sekiranya ibumu mempunyai hutang, bukankah engkau yang melunasi?" Wanita itu menjawab, "Ya." Lantas Nabi berkata: "Penuhilah hutang Allah, sebab Allah lebih berhak untuk dilunasi hutangnya". ${ }^{34}$

Hadis ini menjelaskan tentang bolehnya melakukan badal haji orang tua yang telah wafat, karena mereka sudah mampu dan memiliki kewajiban untuk melaksanakan rukun Islam yang kelima. Namun, orang tua yang telah wafat dan belum melaksanakannya, maka anak yang diharuskan untuk melaksanakan, karena pada hakikatnya hal ini termasuk indikator birr al-Wâlidayn setelah wafat.

Selama anak sudah melaksanakan rukun Islam yang kelima untuk dirinya sendiri, maka lebih utama anak yang melaksanakan badal haji untuk orang tuanya yang belum sempat melaksanakan pada masa hidupnya, karena pada hakikatnya terdapat nilai-nilai birr al-Walidain. Namun, melihat lebih jauh, jika anak tidak memungkinkan untuk melaksanakan dengan sendirinya, maka anak tersebut menyerahkan badal haji untuk orang tuanya kepada orang lain yang dianggap mampu.

\section{Menyambung Silaturahmi dengan teman dan kerabat orang tua}

Kata silaturahmi secara bahasa berarti menyambung tali persaudaraan, ${ }^{35}$ karena hal tersebut merupakan perintah Allah dalam Al-Qur'an ataupun hadis, serta keutamaan silaturahmi akan mendatangkan keridaan Allah Swt., sehingga mempererat tali persaudaraan dan terhindar dari perpecahan antara umat Islam. Firman Allah dalam Al-Qur'an surah Âli Imrân [3]: ayat 15:

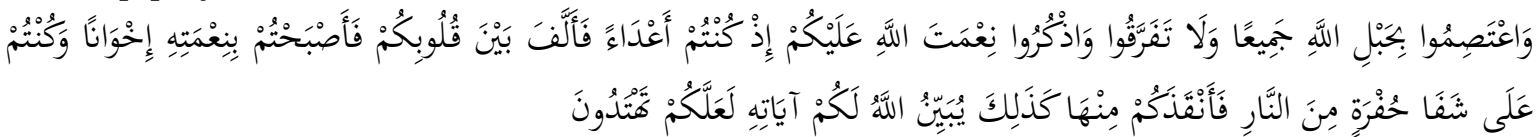

"Dan berpeganglah kamu semuanya kepada tali (agama) Allah, dan janganlah kamu bercerai berai, dan ingatlah akan nikmat Allah kepadamu ketika kamu dahulu (masa

\footnotetext{
33 Ahmad Thib Raya \& Siti Musdah Mulia, Menyelami Seluk-Beluk ibadah dalam Islam (Jakarta Tmur: Kencana, 2003), hlm. 321

${ }_{34}$ Abu Abdullah Muhammad bin Ismail Al-Bukhari, Ensiklopedia Hadits Shahih Al-Bukhari juz 1, trj. Masyhar dan Muhammad Suhadi (Jakarta: Almahira, 2011), hlm. 414

35 Departemen Pendidikan Nasional, Kamus Besar Bahasa Indonesia, hlm. 1306
} 
Studi Living Qur'ân Implementasi Pemahaman Masyarakat Terhadap Surah Al-Nisâ' Ayat 36 Tentang Birr Al-Wâlidayn Setelah Wafat Di Desa Omben Kecamatan Omben Kabupaten Sampang

Jahiliyah) bermusuh-musuhan, maka Allah mempersatukan hatimu, lalu menjadilah kamu karena nikmat Allah, orang-orang yang bersaudara; dan kamu telah berada di tepi jurang neraka, lalu Allah menyelamatkan kamu dari padanya. Demikianlah Allah menerangkan ayat-ayat-Nya kepadamu, agar kamu mendapat petunjuk. ${ }^{36}$

Terputusnya nyawa orang tua, bukan berarti dia telah memutuskan segalanya, silaturahmi sesama temannya akan tetap bersambung ketika anak tidak memutuskan silaturahmi terhadap mereka, karena secara jelas tidak ada pernyataan bahwa silaturahmi dilakukan pada masa hidupnya saja, tetapi setelah wafatnya orang tua, seharusnya silaturahmi tersebut disambung oleh anaknya.

Mengingat pentingnya menyambung silaturahmi kepada teman orang tua yang telah wafat, termasuk indikator birr al-Walidain, karena perbuatan baik yang dilakukan anak untuk kedua orang tuanya, menandakan bahwa anak telah membahagiakan orang-orang terdekat dengan orang tuanya.

\section{Implementasi Pemahaman Masyarakat Terhadap Surah Al-Nisâ' Ayat 36 Tentang Birr Al-Wâlidayn Setelah Wafat Di Desa Omben Kecamatan Omben Kabupaten Sampang}

Sebelum penulis menguraikan tentang implementasi pemahaman masyarakat terhadap surah al-Nisâ' ayat 36 tentang birr al-Wâlidayn, maka perlu diketahui sekilas tentang penafsiran ayat tersebut.

Surah al-Nisâ' ayat 36 merupakan salah satu ayat yang menunjukkan perintah untuk berbakti kepada kedua orang tua, terdapat beberapa penafsiran yang menjelaskan ayat tersebut, baik penjelasan yang secara global sampai pada penjelasan yang bersifat rinci dan detail, sebagaimana berikut penjelasannya.

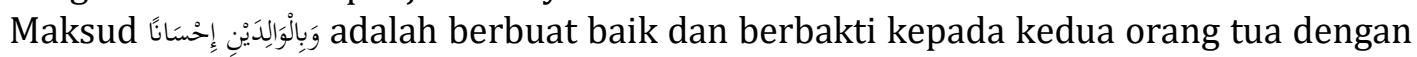
cara melayani mereka dengan baik, menjalankan perintah orang tua, taat dan patuh, tidak melakukan hal-hal yang dapat menyakitkan hati kedua orang tua, menafkahi mereka sesuai kemampuan anak, berperilaku sopan dan bertutur kata yang halus dan lembut. ${ }^{37}$

Ayat di atas merupakan salah satu perintah untuk berbakti dan berbuat baik kepada kedua orang tua, M. Quraish Shihab dalam ayat ini menyinggung dua perbuatan yang berkaitan dengan kedua orang tua, yaitu; pertama, orang tua yang tidak beragama Islam dan perintahnya keluar dari ajaran Islam, maka anak menyikapinya dengan cara makruf, dengan artian anak tidak rela terhadap apa yang telah dilakukan orang tua, tetapi ketidak relanya anak tidak boleh mendurhakai mereka. Kedua, jika orang tua beragama Islam, maka anak diharuskan untuk melakukan ihsan kepada mereka. ${ }^{38}$

Ayat tersebut menyatakan secara jelas, perbedaan yang harus dilakukan anak kepada kedua orang tua yang menganut agama Islam dan tidak, sehingga dapat dikatakan bahwa berbuat makruf memiliki arti yang lebih umum dan dilakukan pada siapa saja yang sedang dihadapi, sedangkan ihsan mengkhususkan kepada kedua orang tua.

\footnotetext{
36 Departemen Agama RI, Al Qur'an dan Terjemahnya, hlm. 93

37 Wahbah Az-Zuhaili, Tafsir Al-Munir. Aqidah, Syari'ah, \& Manhaj jilid 3, hlm. 85-88

${ }^{38}$ M. Quraish Shihab, Tafsir Al-Mishbah Pesan, Kesan, dan Keserasian Al-Qur'an (Jakarta: Lentera Hati, 2002), hlm. 530
} 
Ariej

Dalam tafsir lain disebutkan bahwa anak diharuskan berbakti dan berbuat baik kepada kedua orang tua, karena mereka menjadi sebab adanya anak ke dunia dari tidak ada menjadi ada, bahkan banyak ayat tentang berbakti kepada kedua orang tua bersanding dengan perintah beribadah kepada Allah Swt. ${ }^{39}$

Bersandingnya perintah berbakti kepada kedua orang tua dengan perintah menyembah Allah menunjukkan bahwa perintah tersebut merupakan sesuatu yang mulia dan keharusan untuk dilaksanakan bagi setiap anak terhadap kedua orang tuanya.

Dalam Tafsir Al-Azhar, Hamka menjelaskan bahwa anak diharuskan untuk menghormati, mengasihi, bersopan-santun kepada kedua orang tua, karena mereka yang telah mengasihi anak tanpa merasa lelah dan payah, ibu yang telah menjaga dan merawat anak sampai beranjak desawa dan bapak yang mencari nafkah demi memenuhi kebutuhan keluarga, sehingga orang tua yang masih hidup, anak diwajibkan untuk berperilaku sopan dan mengormati sebagai balas budi anak terhadap mereka. Jika kedua orang tua telah wafat, maka sebagai diharuskan mendoakan mereka dan memohonkan ampunan atas segala dosadosa orang tua. ${ }^{40}$

Penafsiran ini sudah mengarah kepada bakti anak terhadap kedua orang tua yang masih hidup dan setelah wafat, karena sebagai bentuk timbal balik kepada orang tua yang telah menjaga dan merawat anak sejak dalam kandungan sampai dewasa, bahkan sampai berkeluarga. Jika orang tua telah wafat, bentuk baktinya dengan cara medoakan dan memohonkan ampunan kepada mereka, karena pahalanya akan sampai dan dapat dirasakan di alam kubur. Hal ini, dapat membuktikan bahwa birr al-Wâlidayn juga dilakukan meskipun orang tua telah wafat.

Implementasi pemahaman masyarakat terhadap surah al-Nisâ' ayat 36 tentang birr al-Wâlidayn setelah wafat di desa Omben kecamatan Omben kabupaten Sampang dapat dibedakan menjadi beberapa bagian, sesuai dengan realita yang ada di desa tersebut. Seperti kegiatan tahlilan, membacakan ayat suci Al-Qur'an, membaca zikir, mendoakan dan bersedakah yang dihadiahkan untuk orang tua yang telah wafat, memperingati empat puluh harinya setelah wafatnya, seratus harinya, haul, seribu harinya, dan ziarah ke kuburan orang tua. Penulis akan memaparkan sebagai berikut.

\section{Tahlilan}

Tahlil merupakan bacaan la ilaha illallah, sedangkan tahlilan adalah bacaan-bacaan yang dilakukan secara bersama, baik berupa ayat suci Al-Qur'an, zikir, doa ataupun sedekah yang dihadiahkan untuk arwah yang telah meninggal dunia. ${ }^{41}$ Secara terminologi, tahlilan adalah kebiasaan yang dilakukan dengan cara berkumpul bersama saudara, sanak famili, teman, dan tetangga selama tujuh hari, dilakukan ketika ada seseorang yang meninggal dunia. Tahlil dimulai dengan pembacaan surat al-Fatihah untuk arwah sesepuh yang telah

${ }^{39}$ Abdullah bin Muhammad bin Abdurrahamn Alu Syaikh, Tafsir Ibnu Katsir jilid 2, trj. M. Abdul Ghoffar (Tt: Pustaka Imam Asy-Syafi'i, 2011), hlm. 30

${ }^{40}$ Hamka, Tafsir Al Azhar Juzu' 4 (Jakarta: Pustaka Panjimas, 1983), hlm. 63-64

${ }^{41}$ Departemen Pendidikan Nasional, Kamus Besar Bahasa Indonesia, hlm. 1376 
Studi Living Qur'ân Implementasi Pemahaman Masyarakat Terhadap Surah Al-Nisấ' Ayat 36 Tentang Birr Al-Wâlidayn Setelah Wafat Di Desa Omben Kecamatan Omben Kabupaten Sampang

meninggal, dilanjutkan dengan pembacaan Yasin, kemudian pembacaan tahlil dan diakhiri dengan doa. ${ }^{42}$

Tradisi tahlilan bermula dari kebiasaan Hindu-Budha yang memiliki kepercayaan Animisme. Menurut mereka, seseorang yang meninggal dunia akan datang, pada malam hari ruhnya akan datang ke rumahnya dan mengunjungi keluarganya, dan jika di rumah tersebut dalam keadaan sepi dan tidak ada orang yang berkumpul untuk melakukan sesaji, maka ruh orang yang meninggal akan marah dan masuk ke dalam diri orang yang hidup..$^{43}$

Kedatangan Wali Songo tidak menghilangkan kegiatan tersebut, tetapi mengganti isinya degnan bacaan-bacaan keislaman. Sesaji diganti dengan nasi dan lauk yang disebut shodaqah, pembacaan mantra-mantra diganti dengan bacaan ayat suci al-Quran, zikir dan doa, kemudian kegiatan ini dinamakan tahlilan.44

Adanya tradisi tahlilan, terkadang diterima dengan baik, karena untuk mendoakan orang yang telah meninggal dunia. Namun, sebagian yang lain tidak mengakui adanya kegiatan tahilan, karena tidak ada nash yang jelas dan tidak dicontohkan atau dilakukan pada zaman Rasulullah saw., serta dianggap menghambur-hamburkan uang orang yang terkena musibah.

Memperingati orang tua yang sudah wafat, tidak hanya dilakukan beberapa hari saja, tetapi terdapat waktu-waktu khusus yang dianggap penting untuk diperingati, diibaratkan dengan memperingati hari kelahiran Nabi Muhammad saw., maka memperingati hari kematian dengan hal-hal yang baik juga dianjurkan. Kesadaran anak untuk mengadakan kegiatan tahlilan yang dihadiri oleh kerabat dan tetangga, dengan membacakan ayat-ayat suci Al-Qur'an, zikir dan doa yang dipanjatkan, akan memberikan dampak yang baik untuk orang tua yang telah wafat, karena semakin banyak orang yang mengirimkan hadiah berupa bacaan-bacaan tersebut, maka semakin mustajab. ${ }^{45}$ Di antara bacaan-bacaan yang dilakukan dalam tahlilan, yaitu sebagai berikut:

\section{Membaca Ayat Suci Al-Qur'an}

Membaca ayat suci Al-Qur'an dengan beberapa keutamannya, jika dibacakan oleh anak dan bacaan tersebut ditujukan atau dihadiahkan kepada orang tua yang telah wafat, maka pahalanya akan sampai dan akan dirasakan oleh mereka dalam alam kubur, ${ }^{46}$ dan ulama sepakat akan sampainya pahala kebaikan tersebut kepada orang yang telah meninggal dunia. ${ }^{47}$

42 Muhyiddin Abdusshomad, Fiqh Tradisionalis Jawaban Pelbagai Persoalan Keagamaan Sehari-hari (Malang: Pustaka Bayan, 2004), hlm. 234

${ }^{43}$ Syahrin Harahap dan Hasan Bakti Nasution, Ensiklopedia Akidah Islam (Jakarta: Kencana, 2009), hlm. 603

44 Ibid., hln. 604

45 Taufiqurrahman, Tokoh Agama di Dusun Bringin Desa Omben. Wawancara langsung (17 Maret 2019)

${ }^{46}$ Ahmad Kamil Fauzi, Doa-Doa Mustajab Anak Khusus untuk Orang Tua Agar Bahagia Dunia \& Akhirat, hlm. 169

${ }^{47}$ Fathy Syamsuddin Ramadlan An Nawiy, Amalan Sholeh yang Dianggap Bid'ah Menghilangkan Kerikil Tajam Perbedaan Menuju Persatuan Umat (Bogor: Al Azhar Fresh Zone Publishing, 2014), hlm. 54 
Dalam kegiatan tahlil, biasanya pembacaan ayat suci Al-Qur'an, semisal surah alFatihah dan Yasin mengawali bacaan-bacaan yang lain, selain karena Al-Qur'an memiliki kedudukan yang tinggi, ia juga dapat menjadi doa atau rahmat bagi orang tua.

\section{Berzikir}

Zikir berasal dari kata dzakara-yadzkuru-dzikran yang berari mengingat, dan menyebut, ${ }^{48}$ ucapan yang diulang-ulang untuk mengingat dan memuji Allah Swt. ${ }^{49}$ Sedangkan secara syariat, zikir adalah mengingat Allah baik dilakukan secara bersamaan dengan ibadahnya, semisal salat, puasa, dan haji, dan yang dilakukann secara terpisah dari ibadah itu sendiri.50 Allah menjamin pahala dan ampunan bagi mereka, sebagaimana dalam Firman-Nya dalam surah al-Hasyr: [59] ayat 10:

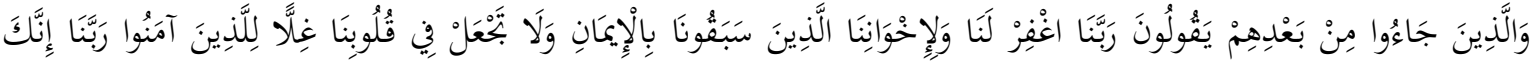

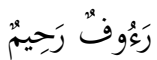

"Dan orang-orang yang datang sesudah mereka (Muhajirin dan Anshor), mereka berdoa: "Ya Rabb kami, beri ampunlah kami dan saudara-saudara kami yang telah beriman lebih dulu dari kami, dan janganlah Engkau membiarkan kedengkian dalam hati kami terhadap orang-orang yang beriman; Ya Rabb kami, Sesungguhnya Engkau Maha Penyantun lagi Maha Penyayang. ${ }^{51}$

Zikir ada kalanya dilakukan dengan sendiri-sendiri atau bersama-sama. Namun, semua bentuk zikir baik, selama tidak keluar dari apa yang telah diajarkan Rasulullah Saw dalam Al-Qur'an atau hadis. Zikir yang dilakukan sendiri-sendiri akan mendapatkan banyak faedah dan terhindar dari sifat riya', sedangkan zikir secara berjamaah, mendatangkan kekhusuan dan mendapatkan rahmat Allah Swt., bahkan doa secara bersama-sama lebih banyak pengaruhnya bagi diri sendiri dan orang lain. ${ }^{52}$

Zikir yang dilakukan dengan berjamaah pada kegiatan tahlilan lebih banyak faedahnya pada orang tua yang meninggal dalam terkabulnya, sehingga hal ini termasuk indikator birr al-Wâlidayn setelah wafat.

\section{Doa dan sedekah}

Doa berarti sebuah seruan, ${ }^{53}$ doa berasal dari bahasa Arab, disebut al-duấ yang bermakna mengajak, mengundang, atau memanggil. Sedangkan secara istilah, doa merupakan sebuah permohonan kepada Allah Swt. supaya dilimpahkan kebaikan dan terhindar dari bahaya. Nabi Muhammad Saw. menyatakan bahwa doa adalah otaknya ibadah

\footnotetext{
48 Subchan Bashori, Pedoman Zikir dan Doa Sesuai Al-Qur'an dan Sunnah Nabi Saw (Surabaya: Muamalah Berkah Sejahtera, 2008), hlm. 1

${ }^{49}$ Departemen Pendidikan Nasional, Kamus Besar Bahasa Indonesia, hlm. 1571

${ }^{50}$ Subchan Bashori, Pedoman Zikir dan Doa Sesuai Al-Qur'an dan Sunnah Nabi Saw, hlm. 1

${ }^{51}$ Departemen Pendidikan Nasional, Kamus Besar Bahasa Indonesia, hlm. 917

52 Usman Said Sarqawi, Zikrullah Urgensinya dalam Kehidupan (Bandung: Remaja Rosdakarya. 2013), hlm. 65-69

53 A.W. Munawwir, Kamus Al-Munawwir Arab-Indonesia Terlangkap (Surabaya: Pustaka Progressif, 1997), hlm. 406
} 
Studi Living Qur'ân Implementasi Pemahaman Masyarakat Terhadap Surah Al-Nisâ' Ayat 36 Tentang Birr Al-Wâlidayn Setelah Wafat Di Desa Omben Kecamatan Omben Kabupaten Sampang

(mukh al-Ibadah) dan sebagai jantung amaliyah seorang mukmin. ${ }^{54}$ Dalam Kamus Besar Bahasa Indonesia, doa merupakan sebuah permohonan, permintaan, pujian yang disampaikan atau diutarakan kepada Allah Swt. ${ }^{55}$

Berdoa merupakan sebuah kegiatan ibadah yang mampu dilakukan oleh siapapun sesuai dengan ketentuan masing-masing, seperti penggunaan bahasa, tempat serta waktu untuk berdoa. Banyak berdoa juga dianggap banyak ibadah, sedangkan sedikit berdoa menunjukkan malas beribadah, sehingga ajaran Islam menganjurkan untuk berdoa, supaya selalu merasa tentram dan tentram dalam menjalankan kehidupan.56 Firman Allah dalam alQuran surah Ghâfir: [40] ayat 60:

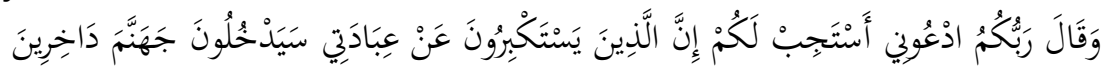

Dan Tuhanmu berfirman: "Berdoalah kepada-Ku, niscaya akan Kuperkenankan bagimu. Sesungguhnya orang-orang yang menyombongkan diri dari menyembah-Ku akan masuk neraka Jahannam dalam keadaan hina dina". ${ }^{57}$

Kata doa pada ayat ini bermakna ibadah, karena setiap ibadah mengandung arti permohonan, sedangkan permohonan yang hakiki disampaikan secara tulus dan ikhlas kepada Allah Swt. Hikmah yang terdapat dalam ayat ini, menunjukkan bahwa Allah mencintai hamba-hambanya yang memohon kepada-Nya, sehingga doa dianjurkan setiap waktu. Seseorang seharusnya tidak hanya berdoa pada waktu mendapatkan kesulitan, menunjukkan rendahnya moral. 58

Doa yang dipanjatkan oleh anak memiliki keistimewaan tertentu, doanya lebih mustajab daripada doa orang lain, karena terdapat keterikatan darah dan batin antara keduanya, sehingga orang tua yang sudah wafat butuh doa dari anak sebagai permohonan ampunan dan keselamatan di alam kubur. Dan bersedekah untuk orang tua, yaitu secara bahasa berarti memberikan sesuatu, terdapat hadis yang menyebutkan:

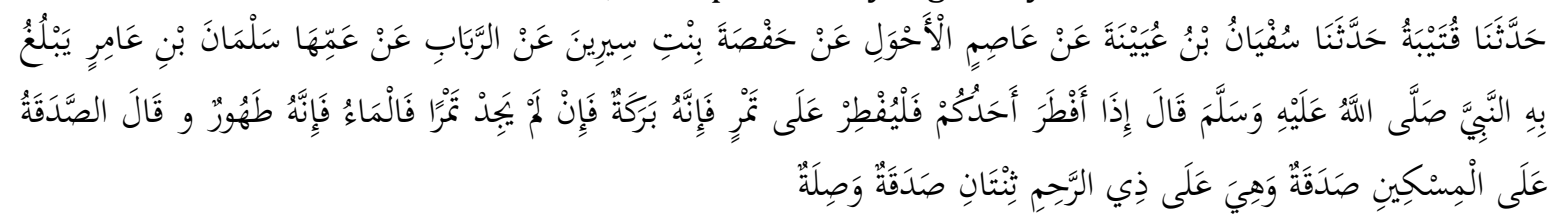

"Telah menceritakan kepada kami Qutaibah telah menceritakan kepada kami Sufyan bin 'Uyainah dari 'Ashim Al Ahwal dari Hafshah binti Sirin dari Ar Rabab dari pamannya Salman bin 'Amir yang membawanya kepada Nabi Shallallaahu 'alaihi wasallam, beliau bersabda: "Jika kalian berbuka maka berbukalah dengan buah kurma karena buah kurma mengandung berkah, jika kalian tidak mendapatinya, maka berbukalah dengan air karena sesungguhnya air itu suci." Beliau juga bersabda: "Sedekah kepada orang

\footnotetext{
${ }^{54}$ Syahrin Harahap dan Hasan Bakti Nasution, Ensiklopedia Akidah Islam, hlm. 94

55 Departemen Pendidikan Nasional, Kamus Besar Bahasa Indonesia (Jakarta: Gramedia Pustaka Utama, 2008), hlm. 337

56 Syahrin Harahap dan Hasan Bakti Nasution, Ensiklopedia Akidah Islam, hlm. 94-95

${ }^{57}$ Departemen Agama RI, Al Qur'an dan Terjemahnya, hlm. 767

${ }^{58}$ M. Quraish Shihab, Tafsir Al Mishbah: Pesan, Kesan dan Keserasian Al-Qur'an, hlm. 649-650
} 
Ariej

miskin hanyalah sedekah, sedangkan sedekah kepada kaum kerabat akan mendapatkan dua (pahala) yaitu pahala sedekah dan menyambung silatur rahmi. ${ }^{59}$

\section{Memperingati Empat Puluh Hari wafatnya Orang Tua}

Memperingati empat puluh harinya orang tua yang telah wafat menjadi kebiasaan di desa Omben, hal ini dianggap lebih utama dan lebih banyak manfaatnya bagi orang tua yang telah wafat, karena doa yang panjatkan dan bacaan ayat suci Al-Qur'an yang pahalanya dihadiahkan kepada kedua orang tua yang telah wafat, maka kegiatan ini terdapat implementasi birr al-Wâlidain setelah wafat.

\section{Memperingati Seratus Harinya wafatnya Orang Tua}

Memperingati hari wafatnya orang tua yang ke seratus harinya merupakan kebiasaan yang dilakukan oleh masyarakat desa Omben dengan mengundang saudara dan tetangga. Kegiatan ini diisi dengan bacaan ayat suci Al-Qur'an, zikir, doa dan sedekah. Hal ini sesuai dengan teori pada sub bab sebelumnya bahwa salah satu bentuk berbakti dan berbuat baik kepada kedua orang tua dengan cara mendoakan dan memohonkan ampunan, membacakan ayat suci Al-Qur'an, yang pahalanya dihadahkan kepada kedua orang tua yang telah meninggal.

\section{Memperingati Satu Tahun (Haul) Wafatnya Orang Tua}

Haul secara bahasa berarti tahun, ${ }^{60}$ orang tua yang telah wafat dan mencapai satu tahun, anak memperingatinya dengan mengadakan kegiatan haul atau disebut taonah oreng seppo, tahun pertama disebut dengan haul ke-1, haul ke-2 dan seterusnya.

Kegiatan ini, biasanya dilakukan dengan cara mengundang kiai, nyai dan santrinya untuk menghatamkan Al-Qur'an dari am 07:00-14:00, kemudian dilanjutkan dengan zikir bersama dan doa sebagai penutup. Hal tersebut terdapat implementasi birr al-Wâlidain setelah wafat, karena kegiatan tersebut pada intinya mendoakan orang tua, semoga selamat dari siksa kubur. ${ }^{61}$

\section{Memperingati Seribu Hari wafatnya Orang Tua}

Memperingati seribu harinya orang tua yang telah wafat disebut dengan muang dâun, kegiatan ini merupakan kegiatan paling akhir dan penutup dari beberapa kegiatan sebelumnya. Namun, bukan berarti selanjutnya anak melupakan dan tidak mendoakan mereka, tetapi melalui kegiatan lainnya.

Kegiatan memperingati seribu hari tersebut di isi dengan hataman Al-Qur'an, zikir, salawat dan diakhiri dengan doa yang dihadiahkan kepada orang tua yang telah wafat, kemudian terdapat jemuan makanan sebagai sedekahnya orang tua pula. Sehingga dalam kegiatan ini terdapat implementasi birr al-Wâlidaîn setelah wafat, sesuai dengan teori pada sub bab sebelumnya.

\footnotetext{
${ }^{59}$ Abi 'Isa Muhammad bin Isa bin Saurah, Sunan Al-Tirmidziy (Libanon, Dar Al-Fikr, th), hlm. 142

60 Mahmud Yunus, Kamus Arab-Indonesia, hlm. 111

${ }^{61}$ Hasan, Warga Dusun Laoden, Observasi Langsung (23 Maret 2019)
} 
Studi Living Qur'ân Implementasi Pemahaman Masyarakat Terhadap Surah Al-Nisâ' Ayat 36 Tentang Birr Al-Wâlidayn Setelah Wafat Di Desa Omben Kecamatan Omben Kabupaten Sampang

\section{Rebbôa}

Asal mula nama rebbâ diambil dari nama dari bulan hijriah, yaitu bulan Sya'ban yang dihimpit oleh bulan Rajab dan Ramadlan, orang Madura menyebutnya rebbâ. Orang Islam meyakini dengan manfaat dan keutamaan sedekah, baik untuk diri sendiri dan orang lain, sehingga orang Indonesia, khususnya di desa Omben memberikan sedekah kepada kiai atau ustaz, dengan harapan mereka mendoakan kepada kedua orang tua yang telah wafat dan pahalnya dihadiahkan kepada mereka, sehingga disebut dengan istilah rebbânah embuk ben eppak. ${ }^{62}$

Pelaksanaan rebbâ berupa pemberian nasi satu piring beserta lauknya dan kopi secangkir pada hari kamis sore atau hari jumat. Seiring berkembangnya zaman, kegiatan ini tidak hanya dilakukan pada bulan rebbâ saja, yang tujuannya untuk mensedekahkan orang tua yang telah wafat.

\section{Ziarah ke Kuburan Orang Tua yang telah Wafat}

Anak yang menyadari akan pentingnya doa yang dipanjatkan oleh anak dan bakti anak untuk kedua orang tuanya meskipun telah wafat, ia akan berupaya melaksanakan semua kebaikan yang berhubungan dengan orang tua untuk kebahagian mereka di alam kubur.

Salah satu bentuk perbuatan baik yang dilakukan anak untuk kedua orang tuanya yang telah wafat dengan cara ziarah ke kuburan mereka, diawali dengan bacaan ayat suci AlQur'an, zikir, dan doa. Kemudian pahala bacaan tersebut dihadiahkan kepada mereka, dengan harapan kedua orang tua yang telah wafat diselamatkan dari siksa kubur dan diampuni segala dosanya, hal tersebut terdapat bentuk nilai birr al-Wâlidayn setelah wafat, sebagaimana dijelaskan pada bab sebelumnya.

Di Samping itu, anak melakukan kebiasaan membersihkan kuburan orang tua setiap satu bulan sekali, supaya tampak bersih dan nyaman untuk dikunjungi. Anak yang masih menjaga dan menghormati kedua orang tua yang telah wafat, dia akan membersihkan dan merawat kuburannya sebagaimana dia membersihkan rumah semasa hidupnya. Bahkan sebagian orang membangun kuburan orang tuanya, demi menampakan keindahan, tanpa harus membersihkan dengan cara mencabut rumput dan meringankan tanggung jawab anak.

\section{PENUTUP}

Pertama, menunjukkan bahwa pandangan masyarakat tentang birr al-Wâlidayn dapat dibedakan menjadi dua, yaitu birr al-Wâlidayn berupa perkataan dan perbuatan. Kedua, indikator birr al-Wâlidayn setelah wafat berupa tanggung jawab anak untuk mengurus jenazah orang tua seperti memandikan, mengafani, menyalati dan menguburkan jenazah orang tua. Kemudian memintakan maaf kepada kerabat dan tetangga, melunasi hutang, melakukan badal haji untuk mereka, dan menyambung silaturahmi dengan teman orang tua. Ketiga, implementasi pemahaman masyarakat terhadap surah al-Nisâ' ayat 36 tentang birr alWâlidayn setelah wafat di desa omben kecamatan omben kabupaten sampang terdapat beberapa bagian, yaitu kegiatan tahlilan, memperingati empat puluh harinya orang tua yang

${ }^{62}$ Imam, Warga Dusun Sang-Sang Desa Omben, Observasi Langsung (4 April 2019) 
Ariej

telah wafat, seratus hari, satu tahun (haul), seribu hari (nyebuh), rebbâ, dan ziarah ke kuburan orang tua.

\section{DAFTAR PUSTAKA}

Abdurrahamn, Abdullah bin Muhammad bin. Tafsir Ibnu Katsir jilid 2, trj. M. Abdul Ghoffar. Tt: Pustaka Imam Asy-Syafi'i, 2011.

Abdusshomad, Muhyiddin. Fiqh Tradisionalis Jawaban Pelbagai Persoalan Keagamaan Sehari-hari. Malang: Pustaka Bayan, 2004.

Adawiyah, Maulida. Berbakti kepada Orang Tua dalam Ungkapan Al-Qur'an

(Pendekatan Teori Anti Sinonimitas). Skripsi:UIN Sunan Kalijaga, Yogyakarta, 2017

Arif, Syaiful. Bagian Penanggung Jwab di Kecamatan Omben, Wawancara Langsung (20 Maret 2019)

Arikunto, Suharsimi. Prosedur Penelitian Suatu Pendekatan Praktik, Edisi Revisi 2010.

Jakarta: Rineka Cipta, 2010.

Arrofiqi, Ahmad. Implementasi Hadis Birrul Walidain setelah Meninggal Dunia pada Masyarakat Wonokromo (Studi Living Hadis). Skripsi, UIN Sunan Kalijaga, Yogyakarta, 2009.

Ath-Thahir, Fat-hi Muhammad. Berbakti kepada Orang Tua Kunci Kesuksesan \&

Kebahagiaan Anak, trj. Ahmad Hotib. Bandung: Irsyad Baitus Salam, 2006.

Aziz, Maqsudi. Tokoh Agama di Dusun Laodan, Wawancara Langsung (20 Maret 2019)

Aziz, Sa'ad Yusuf Abu. Buku Pintar Sunnah dan Bid'ah. Yogyakarta: Pustaka Al-Kautsar,

2016

Bashori, Subchan. Pedoman Zikir dan Doa Sesuai Al-Qur'an dan Sunnah Nabi Saw. Surabaya: Muamalah Berkah Sejahtera, 2008

Al-Anshariy, Jamal al-Din Abi Al-Fadl Muhammad. Lisan Al-Arab. Libanon: Dar AlFikar, 2009.

Al-Baqiy, Muhammad Fuad Abd. Al-Mu'jam Al-Mufahras Li Alfâdz Al-Qur'an Al-Karîm. Mesir: Dâr Al-Kutub, 1364

Al-Bukhârî, Abi Abdillah Muhammad bin Ismail. Shahîh Al-Bukhârî. Istanbul: Dâr AlFikr, 2005.

Al-Bukhârî, Abi Abdillah Muhammad bin Ismail. Ensiklopedia Hadits Shahih Al-Bukhari juz 1, trj. Masyhar dan Muhammad Suhadi. Jakarta: Almahira, 2011.

Bik, Alwi Abdul Kadir. Birr al-Wâlidayn (Berbakti kepada Kedua Orang Tua. Jakarta: Amzah, 2016.

Buna'i. Metodologi Penelitian Pendidikan (Jakarta: PT Bumi Aksara, 2003.

Departemen Agama RI, Al Qur'an dan Terjemahnya. Surabaya: Al-Hidayah, 2002.

Departemen Pendidikan Nasional, Kamus Besar Bahasa Indonesia. Jakarta: Gramedia Pustaka Utama, 2008. 1999.

Faisal, Sanapiah. Format-Format Penelitian social. Jakarta: RajaGrafindo Persada,

Faraj, Suad Muhammad. Berbakti kepada Ibu Bapak Kewajiban Berbuat Baik kepada Kedua Orang Tua Sesuai Al-Qur'an dan Sunnah Nabi, trj. Achmad Sunarto. Yogyakarta: Mitra Pustaka, 2014.

Fauzi, Ahmad Kamil. Doa-Doa Mustajab Anak Khusus untuk Orang Tua Agar Bahagia Dunia \& Akhirat. Yogyakarta: Araska, 2016

Hamka. Tafsir Al Azhar Juzu’ 4. Jakarta: Pustaka Panjimas, 1983 
Studi Living Qur'ân Implementasi Pemahaman Masyarakat Terhadap Surah Al-Nisâ' Ayat 36 Tentang Birr Al-Wâlidayn Setelah Wafat Di Desa Omben Kecamatan Omben Kabupaten Sampang 2009.

Harahap, Syahrin dan Bakti Nasution. Ensiklopedia Akidah Islam. Jakarta: Kencana,

Hasan. Warga Dusun Laoden, Observasi Langsung (23 Maret 2019)

Hasnijar, Luky. "Konsep Birrul Walidain dalam Al-Qur'an Surat As-Shaffat ayat 102-107

(Kajian Tafsir Fi Zhilal Qur'an),". Skripsi: UIN Ar-Raniry, Darussalam Banda Aceh, 2017.

Hasyim. Warga Desa Omben, Wawancara Langsung (15 Januari 2019)

Imam, Warga Dusun Sang-Sang Desa Omben, Observasi Langsung (4 April 2019)

Jalil, Abd. Profil Desa Omben kecamatan Omben Kabupaten Sampang, 2017

Kahija, YF La. Penelitian Fenomenologis Jalan Memahami Pengalaman Hidup.

Yogyakarta: Kanisius (Anggota IKAPI), 2017

M. Mansyur dkk, Metodologi Penelitian Living Qur'an dan Hadis. Yogyakarta: Teras, 2007.

Mansur. Ustadz di Wakaf Al-Imam desa Omben kabupaten Sampang, Wawancara secara langsung (29 Oktober 2018)

Masrur, M. Fatih dan Miftahul Asror, Adab Silaturahmi. Jakarta: Artha Rivera, tt.

Mukhtar. Metode Praktis Penelitian Deskriptif Kualitatif. Jakarta Selatan: Referensi (GP

Press Group), 2013.

Mulia, Ahmad Thib Raya \& Siti Musdah. Menyelami Seluk-Beluk ibadah dalam Islam.

Jakarta Tmur: Kencana, 2003.

Al Munawar, Said Agil Husain. Al-Qur'an Membangun Tradisi Kesalehan Hakiki. Jakarta

Selatan: Ciputat Press, 2002.

Munawwir, Ahmad Warson. Kamus Al-Munawwir Arab-Indonesia Terlengkap.

Surabaya: Pustaka Progressif, 1997.

Mustaqim, Abdul. Metode Penelitian Al-Quran dan Tafsir. Yogyakarta: Lkis, 2010

Nada, Abdul Aziz bin Fathi As-Sayyid. Ensiklopedia Adab Islam Menurut Al-Qur'an dan

As-Sunnah. Trj. Abu Ihsan Al-Atsari. Jakarta: Pustaka Imam Asy-Syafi'i, 2007.

Nawawi, Imam. Syarah Shahih Muslim. Jakarta: Darus Sunnah, 2015.

Al-Nasa'i, Ahmad bin Syu'aib Abu Abdurrahman. Ensiklopedia Sunan Al-Nasa'i, trj. M.

Khairul Huda, dkk. Jakarta: Almahira, 2013.

An Nawiy, Fathy Syamsuddin Ramadlan. Amalan Sholeh yang Dianggap Bid'ah

Menghilangkan Kerikil Tajam Perbedaan Menuju Persatuan Umat. Bogor: Al Azhar Fresh Zone

Publishing, 2014.

Nufus, Fika Pijaki. "Konsep Pendidikan Birrul Walidain dalam QS. Luqman (31): 14 dan QS. Al-Isra (17): 23-24." Jurnal Ilmiah Didaktika, Vol. 18. No. 1 (Agustus 2017).

Pondok Pesantren Safinah Al-Huda. Buku Panduan Program Pelatihan Terjemah Al-

Qur'an juz 2, (17 Maret 2010).

Putra, Heddy Shri Ahimsa. "The Living Al-Qur'an: Beberapa Perspektif Antropologi."

Journal Walisongo. Vol. 20, No. 1 (Mei 2012)

Riduwan. Metode \& Teknik Menyusun Proposal Penelitian. Bandung: Alfabeta, 2015.

Rois, Moh. Guru dan Aparat Desa, Wawancara Langsung (10 April 2019)

Royyan, Mohammad Danial. Sejarah Tahlil Kumpulan Tahlil, Talqin, dan Ziarah Kubur

dalam Sejarah dan Argumentasinya. Kendal: LTN-NU dan Pustaka Amanah, 2013.

Sa'dulloh. 9 Cara Cepat Menghafal Al-Qur'an. Jakarta: Gema Insani, 2008.

Saifuddin. Guru Ngaji di Desa Omben, Wawancara Langsung (Maret 2019) 
Ariej

Salamah. salah satu pelaksana kegiatan Tahlil, empat puluh hari, haul dan seribu hari, Wawancara secara langsung (29 Oktober 2018)

Sarqawi, Usman Said. Zikrullah Urgensinya dalam Kehidupan. Bandung: Remaja Rosdakarya. 2013.

Saurah, Abi 'Isa Muhammad bin 'Isa bin. Sunan Al-Tirmidziy. Libanon, Dar Al-Fikr, th.

Shihab, M. Quraish. Tafsir Al Mishbah: Pesan, Kesan dan Keserasian Al-Qur'an, Vol.2 Jakarta: Lentera Hati, 2002.

Shihab, M. Quraish. Tafsir Al-Mishbah Pesan, Kesan, dan Keserasian Al-Qur'an, Vol.7 (Jakarta: Lentera Hati, 2002),

Suharsaputra, Uhar. Metode Penelitian Kuantitatif, Kualitatif, dan Tindakan. Bandung: Refika Aditama, 2012

Syafi'i. Warga Desa Omben, Wawancara Langsung (Maret 2019)

Asy-Syanqithi. Tafsir Adhwa'ul Bayan Tafsir Al-Qur'an dengan Al-Qur'an, trj. Bari dkk. Jakarta: Pustaka Azzam, 2007

Tamri. Tokoh Agama di Dusun Bhutmancâng Desa Omben, Wawancara Langsung (7 April 2019)

Taufiqurrohman, Pengasuh Lembaga Darussalam 2, Wawancara Langsung, (04 Maret

Tim Revisi, Pedoman Penulisan Karya Ilmiah, Edisi Revisi. Pamekasan: STAIN Pamekasan, 2015.

Al-Qazwini, Abi Abdillah Muhammad bin Yazid. Sunan Ibnu Mâjah. Libanon: Dar AlKotob Al-Ilmiyah, 2009.

Al-Qazwini, Abi Abdillah Muhammad bin Yazid. Ensiklopedia Hadits 8; Sunan Ibnu Majah, trj. Saifuddin Zuhri. Jakarta: Al-Mahira, 2013.

Yunus, Mahmud. Kamus Arab-Indonesia. Jakarta: Mahmud Yunus Wadzurriyyah, 1990.

Az-Zuhaili, Wahbah. Tafsir Al-Munir. Aqidah, Syari'ah, \& Manhaj jilid 8, trj. Abdul Hayyie Al-Kattani dkk. Jakarta: Gema Insani, 2016.

Az-Zuhaili, Wahbah. Tafsir Al-Munir. Aqidah, Syari'ah, \& Manhaj jilid 3, trj. Abdul Hayyie Al-Kattani dkk. Jakarta: Gema Insani, 2016. 